\title{
Shopping with a Conscience? The Epistemic Case for Relinquishment over Conscientious Consumption
}

\author{
Ewan Kingston \\ Princeton University
}

\begin{abstract}
Many people argue that we should practice conscientious consumption. Faced with goods from gravely flawed production processes, such as wood from clear-cut rainforests or electronics containing conflict minerals, they argue that we should enact personal policies to routinely shun tainted goods and select pure(r) goods. However, consumers typically should be relatively uncertain about which flaws in global supply chains are grave and the connection of purchases to those grave flaws. The threat of significant uncertainty makes conscientious consumption appear to be no better, or even worse, than an overlooked option. This overlooked option is consumption with relinquishment: disregarding each product's possible connections with upstream grave flaws and using the time, money, and energy saved in this way to address grave flaws directly.
\end{abstract}

Key Words: consumer ethics, social epistemology, supply chains, ethical consumerism, political consumerism

$\mathrm{P}$ eople buy many products that are closely connected to grave flaws: situations so dire that they demand some kind of excuse, justification, or remedy from all those connected with them. For instance, that phone might contain gold that was raided from an artisanal miner in the Congo at gunpoint. That wooden table might be produced from clear-cut rainforests in Indonesia. That T-shirt might have been produced in a highly unsafe factory employing young children as full-time laborers. This list could continue, linking many of the products that we buy with many global labor, environmental, and human rights concerns. Call the products linked to grave flaws in this way morally tainted, as opposed to pure( $r)$ products that lack such intimate connections, such as your neighbor's organic zucchini.

Many of us intuitively think that the appropriate response to the tainted products is to shun them, at least where we can. If we are to buy tables, phones, and T-shirts, we should try to buy the "ethical" table, phone, or T-shirt, those products with the best moral credentials of the feasible options. Difficulties often arise, however, when we consider what it might take to figure out which is the "ethical" table, phone, or T-shirt, especially if the product has come from a global supply chain. If we peer behind superficial marketing, we often find that celebrated certifications of purity 
have their own critics among civil society, with academics suggesting the selection of some purer products does more harm than good. ${ }^{1}$ This article suggests how consumers should respond, given these significant difficulties in knowing which flaws are grave, which purchases are linked to those flaws, and how they are linked.

The consumption practice that I wish to call into question in the case of global supply chains is what I call conscientious consumption:

Conscientious consumption: setting and following personal policies of shunning (or selecting) certain goods, with respect to their apparent connection (or lack of connection) to grave flaws upstream in the supply chain. ${ }^{2}$

This definition contains a few terms of art. I have defined and illustrated the concept of a grave flaw in the opening paragraph. Supply chains begin upstream at sites of initial extraction and refinement of raw materials. Products travel downstream through further producers and intermediaries toward the final consumer. By personal policies, I mean standing intentions to behave a given way in a given circumstance (Bratman 1989). The exact contents of such policies vary depending on the particular resources and circumstances of an agent. They might be narrow and vague, such as $<$ when buying clothing, avoid large department stores $>$; wide and specific, such as $<$ when buying a product over $\$ 15$, select one that is top-rated in its category on the Ethical Consumer website>; or wide and vague, such as <before any purchase, consider what I have heard that might suggest this product is morally tainted $>$. Conscientious consumption is the general practice of setting such policies that cover a range of consumer goods. Technically, because of my focus on global supply chains, one could specify my target as "global-production conscientious consumption," but for brevity, I often refer to this practice merely as conscientious consumption.

Conscientious consumption can be seen as one of three very different approaches to the problem that faces consumers considering tainted products. Another familiar practice is cavalier consumption:

Cavalier consumption: purchasing goods without regard to their apparent connection to grave flaws upstream in the supply chain.

Commonly overlooked is that both conscientious and cavalier consumption can be contrasted with consumption with relinquishment. ${ }^{3}$ This strategy is engaged

\footnotetext{
${ }^{1}$ These suggestions are explored in what follows. A good primer on the epistemic difficulties is Bartley et al. (2015).

${ }^{2}$ In this article, I focus only on conscientious consumption as a response to production processes, not to statements made by firms or their representatives or potential harm caused by the use of these products. I also simplify matters by not considering voluntary simplicity - the reduction of the overall volume of one's consumption of products purchased firsthand. I assume that some new products (e.g., food) must be consumed by all of us sometime, and some of us must purchase new items as old ones become incapable of repair.

${ }^{3}$ See also the excellent article by Benjamin Ferguson and Florian Ostmann (2018), which has provided significant inspiration for this article. However, where Ferguson and Ostmann focus on the act of purchasing in one industry (apparel) and one type of harm (unfair wages), my account is broader. Ferguson and Ostmann also claim that the wrongness of purchasing a tainted product 1) cannot be easily traced to its consequences and 2) can be traced (at least in the cases of unfair wages) to gaining an undeserved benefit. Here I remain open
} 
when the consumer practices cavalier consumption, except that consumer relinquishes the "cavalier dividend"- the time and money saved through not practicing conscientious consumption-toward remedying grave flaws:

Consumption with relinquishment: purchasing goods without regard to their apparent connection to grave flaws upstream in the supply chain and channeling the benefits received to fitting projects.

I will argue that, at least in the case of global supply chains, it is this third, overlooked approach that captures the most appropriate moral response to grave flaws. To put it formally, I wish to argue for a claim I call the adequacy of relinquishment:

Adequacy of relinquishment: in light of the epistemic limitations that ordinary consumers face, they typically have just as much (or more) moral reason ${ }^{4}$ to practice consumption with relinquishment as to practice conscientious consumption.

I argue for the adequacy of relinquishment (and thus against the priority of conscientious consumption) in the following way. In section 1, I suggest several ways in which significant uncertainty on the part of a decision maker in general might lead not only to tweaks to a personal policy but to large changes to the practice of which it forms a part. In section 2, I highlight that defenses of the ethical priority of conscientious consumption typically begin from an assumption that epistemic constraints on consumers are only tangentially relevant. In section 3, I argue that in cases of grave flaws in global supply chains, each individual consumer will plausibly very often be in a situation of significant uncertainty regarding the upstream flaws and the connections of those flaws to given products. In sections $4-6$, I turn to the ramifications of significant uncertainty for different approaches to conscientious consumption, especially different versions of consequentialism and deontology. Section 7 concludes and considers applications of the argument beyond global supply chains.

\section{THE SIGNIFICANCE OF UNCERTAINTY}

Conscientious consumption of global products is promoted by numerous nongovernmental organizations. Very often their calls to consumers to practice conscientious consumption are only implied, as in a spoof Kit Kat commercial produced by Greenpeace, which likens eating a Kit Kat chocolate wafer to eating an orangutan finger due to Nestlé's alleged role in Indonesian rainforest destruction. At other times, conscientious consumption is framed more positively, as when the Slave Free Chocolate coalition tells us that "chocolate consumers have real power. Let's use it

to either proposition being false. Finally, Ferguson and Ostmann's account is not primarily based on epistemic considerations, so we reach similar conclusions via different routes.

${ }^{4} \mathrm{I}$ am referring to subjective moral reasons here-reasons for setting personal policies from the point of view of the agent, as seems appropriate for this context. One could, presumably, discuss the objective moral reasons, but then the debate would turn to whether agents would be blameworthy for practicing relinquishment over conscientious consumption, and the arguments I give could be adapted to show that such agents would not be blameworthy. 
together to help these children." ${ }^{5}$ But it is not only activists who support conscientious consumption; it also has several philosophical advocates (Nefsky 2018; Schwartz 2010; Lichtenberg 2010, 2014; Hassoun 2015, 2019; Hussain 2012b; Føllesdal 2004; Lawford-Smith 2015, 2016; Barry and Macdonald 2018). What is striking about most of the philosophical defenses of conscientious consumption is their focus on clarifying the morally significant relationship(s) between consumers' personal purchasing policies and the upstream grave flaws. The primary philosophical project is taken to be whether purchasing, say, a particular sweatshop-made item is best understood as a causal influence on a grave flaw (Schwartz 2010; Lichtenberg 2010), getting too "close" to wrongdoing (Shepski 2013), participating in a grave flaw (Lichtenberg 2010; Schwartz 2010), a lack of uprightness or solidarity (Micheletti 2003), a lack of "creative resolve" (Hassoun 2015), or something else. In this article, I take no specific stance on what morally significant relationships (if any) apply between purchasing policies and grave flaws. Instead, I argue that the ethical arguments for conscientious consumption are incomplete, since detailing the morally relevant relationship that consumption represents does not necessarily issue in an all-things-considered recommendation for action. Many considerations might count against conscientious consumption. For instance, one might argue that despite morally relevant relationships between purchasing policies and grave flaws, there are countervailing constraints against bringing political concerns into the domain of the marketplace, because it might increase polarization, reduce sound deliberation, or exacerbate political inequalities (Hussain 2012a). In this article, I argue that the poor epistemic situation of consumers blocks any easy route by which personal conscientious consumption policies might be thought to be derived from the morally relevant relationships between purchases and the upstream grave flaw.

Before arguing, in section 3, that consumers are in a position of significant uncertainty, I want to explore what might follow if they are. After all, one might think that uncertainty just feeds straight into the reasons consumers have to set policies, in a simple way. On this view, the extent to which individual consumers are uncertain (about the provenance of a good, the effect of a mass-consumption policy, or the gravity of some flaw) weakens but does not change their reasons to continue practicing consumption. That itself is a particular strategic response to uncertainty, a strategy I call soldier on:

Soldier on: set personal policies based on the imperfect information you have and try to improve your information where feasible.

But it is crucial to realize that soldier on is not the only strategic response to significant uncertainty. Other (non-exclusive) responses might include the following:

Blunder blind: ignore the imperfect information you have completely.

\footnotetext{
${ }^{5}$ http://slavefreechocolate.org/.
} 
Delegate tasks: assign the tasks you would be morally required to undertake under conditions of certainty to agents in a better epistemic position than you, and support them if appropriate.

Avoid uncertainty: set policies that will lead you to operate in domains of much greater certainty.

Because I wish to show how consumers justifiably selecting the strategies of blunder blind and delegate tasks leads to the adequacy of relinquishment thesis, let us explore these responses to uncertainty in more detail. To draw out the difference in these strategies, let us consider a somewhat contrived situation. Obscured's team is traversing a landscape containing land mines. Obscured can try to do good by a policy of actively demining or can just avoid harm (prevent injury to his team). Obscured receives regular maps from central command showing where the land mines might be. But experience has shown that the maps are inaccurate. They routinely show mines where no mines exist and fail to show mines where mines do exist. Drawing on our earlier distinction, Obscured has several (not totally exclusive, nonexhaustive) strategies:

1. Soldier on: keep using the map, trying to ascertain ways in which the information it provides might be filtered or improved.

2. Blunder blind: ignore the map and return to using other methods, or no methods, to try to avoid mines.

3. Delegate tasks: delegate responsibility for mine clearing to a better-informed actor (perhaps a rearguard team with special equipment), and leave a cache of extra rations for them.

4. Avoid uncertainty: avoid the landscape completely, for instance, by shifting to relatively safe sea transport.

One might notice that different costs of seeking or processing information and different ethical theories interact to suggest different strategies. If one takes a consequentialist perspective, and the overall cost of receiving the map each day and picking circuitous routes that avoid the supposed mines is high enough, then Obscured might have an overall moral reason to blunder blind, and to delegate tasks, if this is an option. Alternatively, if deontological considerations against crossing some threshold of risk to the lives or limbs of any of Obscured's team is of paramount importance, avoid uncertainty might be the best option. Soldier on is also still a live option, especially if she is dedicated to doing good by demining and no rearguard is available to whom she can delegate the task. Character-based approaches might think that the appropriate response to uncertainty depends on what would best embody the relevant virtues, perhaps given a special role that Obscured plays.

A similar situation might exist with policies of conscientious consumption. I argue in what follows that consumers have what amount to poor maps of where the tainted products and the pure products are. Should consumers therefore set radical policies that lead them to avoid uncertainty by shunning the whole domain 
of global supply chains (by, for instance, having a policy of <only buy from producers you personally know $>$ )? Is soldier on with conscientious consumption the best approach? Or does the uncertainty suggest that other actors should shoulder more responsibility and that consumers should blunder blind? One might think that, as in Obscured's case, this will depend on the broader ethical perspective, be it consequentialist, deontological, or virtue based. However, I argue that whatever perspective we choose, the combination of blunder blind and delegate tasks is an appropriate response to the significant uncertainty of consumers. This in turn supports the adequacy of relinquishment.

Before I make that argument, it is worth considering the extant philosophical defenses of the priority of conscientious consumption that take into account the significant uncertainty of consumers. ${ }^{6}$

\section{EXISTING TREATMENT OF EPISTEMIC CONSIDERATIONS}

Has the philosophical literature supporting conscientious consumption already taken epistemic considerations into account? Not sufficiently. ${ }^{7}$ I survey in the following pages the brief mentions of the possibility of significant consumer ignorance and how to deal with it in the philosophical literature.

One approach makes the case for personal policies of conscientious consumption on the condition that consumers know enough. For instance, Julia Nefsky (2018, $558 \mathrm{n} 2$ ) begins her account of conscientious consumption by assuming "for the sake of argument" that we know which feasible production processes "would be better" and never returns to the question of what personal policies might be appropriate given that individuals may lack this knowledge. The problem with this approach is that it ignores the crucial issue for practical ethics: what we might $d o$, as consumers, about grave flaws given that we do not know if we know enough.

David Schwartz $(2010,111)$ seems to take the possibility of significant consumer ignorance more seriously than most, asking, "What is a reasonable level of effort to expect in researching the origins of what we buy? If our research is too brief, we risk participating in serious wrongdoing without our knowledge. If we research too long, we risk gridlock in our daily decision making." However, his work raises these questions but does not give a positive account of what a "reasonable level of effort" would be. Instead, he concludes, "while it may in fact set too low a bar, avoiding

\footnotetext{
${ }^{6}$ There is an extensive literature on the moral ramifications of factual ignorance in moral theory (e.g., Smith 1983; Rosen 2008; Jackson 1991; Sepielli 2018; Olsen 2018). I do not engage with these theories for several reasons. First, this literature typically focuses on the ex post moral assessment of individual actions (or characters, or reasons), given what the writer and reader can recognize is (culpable or nonculpable) ignorance of the actor. My approach concerns ex ante moral assessment of individuals' policies or plans given significant uncertainty in a given domain. Second, very often, the debate seems to concern how we should think (or maybe speak) about conduct, whereas my analysis concerns what personal policies we should enact. Thus linking the abstract literature on objective and subjective notions of moral responsibility to my current project is not currently feasible in this work, even if it were desirable.

${ }^{7}$ Sometimes the main epistemic problem is taken to be which particular purchase of a particular product will cause an effect, not significant uncertainty about which goods are pure and which are tainted. See Lawford-Smith (2015) and Kagan (2011).
} 
willful ignorance is a good starting point in attempting to address the epistemological burden of ethical consumerism" (111). But even Schwartz's "low bar" might be an inappropriate response, depending on the quality of information and the costs of "receiving" it. Saying that avoiding willful ignorance is the minimum policy required of consumers rules out blunder blind as a justified response by fiat, which we might not want to do. ${ }^{8}$

Christian Barry and Kate Macdonald (2018) also take pains to outline a form of conscientious consumption sensitive to epistemic concerns, in the context of a general defense against the charge that conscientious consumption can run counter to liberal-democratic values (Hussain 2012a). They hold that conscientious consumers "should question the reliability of their own views and seek additional information (including about the views of others) as a basis for informing and revising their beliefs about appropriate objectives of social change" (217). These are admirably crafted, epistemically sophisticated policies that ideal conscientious consumers might be able to follow. However, they still assume that soldier on is the appropriate response, given significant consumer ignorance.

Nicole Hassoun (2019) takes a more dogmatic approach. She holds that "often we know" when selective consumption "promote(s) positive change" (434). Hassoun goes on to name actual programs she believes "promote positive change" by certifying products that meet a sufficient standard of purity, in particular, the Worker Rights Consortium (WRC) and Fair Trade organizations. Hassoun suggests that informed consumers are under situations of sufficient certainty, at least with regard to several widely used accreditation schemes, to give them strong reasons to practice conscientious consumption in several broad domains (e.g., apparel, foodstuffs). The plausibility of the dogmatic approach will depend in part on the credibility of the programs Hassoun identifies, which we investigate in sections 3.2 and 3.3. ${ }^{9}$

We want to know whether Hassoun's dogmatic approach, Nefsky's abstract approach, or the attempts by Barry and MacDonald and by Schwartz are enough to prevent epistemic considerations undermining the relative ethical adequacy of conscientious consumption. To do that, we need to take a closer look at an empirical issue: Just how ignorant are consumers about global supply chains?

\section{THE UNCERTAINTY OF CONSUMERS}

Very little, if anything, in practical ethics is completely certain. One way to frame the question of consumer ignorance is to ask whether consumers face significant uncertainty, where this refers to uncertainty that is major enough to require a positive

\footnotetext{
${ }^{8}$ Schwartz's own example of how avoiding willful ignorance is morally required is justified by an example where students are unwilling to listen to Schwartz's description of the provenance of the chicken in the chicken nuggets they are about to eat. As I discuss in section 7, knowledge in the case of animal agriculture is probably easier to come by than in global supply chains linked to grave flaws, so the call simply to avoid "willful ignorance" by listening to reports one receives might apply only to that context.

${ }^{9}$ See also Herzog (2019) for an account (published as this work was under review) that stresses the importance of the epistemic challenges but is sanguine about the ability of information technology to overcome these. Most of the challenges I raise herein are not likely to be solved using information technology.
} 
argument for soldier on instead of choosing one or more of the other responses surveyed in section 1: blunder blind, avoid uncertainty, or delegate tasks. In what follows, I argue that consumers do face significant uncertainty regarding upstream grave flaws.

\subsection{The Sources of Uncertainty}

Consider the following five factors at play in global supply chains:

1. Supply chain complexity: Manufactured goods typically have supply chains with multiple tiers and branches. To take one example, in 2014, the Apple iPhone 6 was assembled from components produced by 785 suppliers in 31 countries. Sixty of these suppliers themselves had major suppliers in other countries (Ruggie 2018).

2. Supply chain dynamism: These networks are also highly dynamic, as technological improvements, changes in regulatory regimes, changes in consumer tastes, and so on all alter the incentives facing the most powerful actors in global supply chains.

3. Wide product ranges: Consumers buy a great number of different product types and, for each type, usually have a wide range of branded and unbranded products from which to choose.

4. Grave flaw complexity: The problems that conscientious consumption is often touted to solve are themselves deeply complex. For instance, demand for forest products might be a potential cause of deforestation, but interact in complicated ways with the institutional treatment of collective land rights of indigenous people, the relative demand for other products, institutional payments for ecosystem services, and so on (Bartley et al. 2015, 85-111).

5. Perspective constraints: The deep differences between the daily lives of an affluent consumer and many of those living and working upstream makes understanding the needs and trade-offs of upstream actors difficult. Even where consumers are in the same culture as the upstream actors, consumers may lack the appropriate standpoint to imagine what constitutes a morally unacceptable production process involving people from very different socioeconomic backgrounds (Schwartz 2010, 107ff.).

These five factors make it likely that consumers will often make mistakes. They might mistake a product's provenance, for instance, if their belief that a given widget's supply chain is free of bonded labor is false (White 2015). They might also mistake the effect of concerted consumer action, for instance, if their belief that a decrease in demand for minerals from the strife-ridden areas of the Democratic Republic of Congo (DRC) would lead to a reduction, rather than an increase, in violence there is false. ${ }^{10}$ They might mistakenly assess the comparative gravity of a

\footnotetext{
${ }^{10}$ One of the only studies on unintended consequences of corporate avoidance of DRC conflict minerals suggests that, in response to declining demand for 3TG from conflict areas, the militias themselves have
} 
flaw, for instance, if their belief that an upstream supplier refusing to hire children must be better than it hiring otherwise highly vulnerable children is false (Cadot, Traca, and Crawford 2001; Hyde 2006; Powell and Zwolinski 2012). Prevalence of any of these mistakes will be significant when they reach a level that triggers us at least to consider that a response other than soldier on is warranted.

In response to this challenge, one might point out that it is not up to the individual consumer to peer into the complex and dynamic supply chains behind the goods she buys. Instead, the consumer has the help of what I call consumer-information infrastructure: mainstream and social media, independent and business-led regulation schemes, and conscientious consumption guides. ${ }^{11}$ Conscientious consumers can draw on this infrastructure to help them navigate the complex global production networks to deliver credible information about better and worse production processes.

However, the information infrastructure itself faces serious challenges. Supply chain complexity and dynamism mean that effectively auditing a single company's supply chain is too costly for most nonprofit organizations to perform feasibly and in a fully comprehensive manner. Product range also presents a significant difficulty for conscientious consumption guides. After all, such guides try to collate and synthesize a huge range of already poor-quality information about grave flaws in supply chains, meaning they have to rely heavily on companies' self-reports and employ idiosyncratic methods, such as searching for key words related to grave flaws in news stories. ${ }^{12}$ Independent certification and monitoring schemes, such as Fairtrade, Fair Wear Foundation, and the Forest or Marine Stewardship Councils, with their narrower focus, can perform somewhat more rigorous analysis of parts of global production networks than conscientious shopping guides can, but such specialized bodies face a number of other problems.

Consider the conflicts of interest facing such organizations within the information infrastructure. It is well known that firms have an incentive to mislead consumers about the ethical qualities of their own products, and many industry-led schemes in the consumer-information infrastructure can be of dubious quality. ${ }^{13}$ But even

turned to substitutes to effectively taxing artisanal miners, instead shifting to the more violent and devastating practice of raiding farming villages (Parker, Aragon, and Parker 2017).

${ }^{11}$ For examples of conscientious consumption guides, see the United Kingdom's Ethical Shopping Guide (https://thegoodshoppingguide.com/) and Ethical Consumer (https://www.ethicalconsumer.org/).

${ }^{12}$ Ethical Consumer's ratings for human rights and workers' rights are particularly idiosyncratic, where companies are down-ranked simply for conducting business in China, Israel, or Russia. Large companies and retailers tend to score lower as a function of their diverse business practices. For instance, Coca-Cola is downgraded for including animal gelatin in some of its massive product range, and clothing retailers are downgraded in the environmental category if they are department stores that also sell petrol (Ethical Consumer 2018). Those guides, such as apparel-focused Good On You (n.d.), which can afford to undertake relatively vigorous research into the supply chains behind various apparel companies, typically rely on funding from the very brands they recommend, creating the kinds of conflicts of interest I discuss later.

${ }^{13}$ For instance, there is some evidence that a chemical manufacturer's membership in the Chemical Manufacturing Association's Responsible Care Initiative was, at least prior to 2002, a signal that the manufacturer was more likely to be a significantly worse polluter than a nonmember (Gamper-Rabindran and Finger 2013)! 
independent civil society schemes have conflicts of interest: the very environmental and labor nongovernmental organizations (NGOs) on whom conscientious consumers tend to rely have subgoals that might align poorly with consumers' epistemic concerns (see, e.g., Singer and van der Ven 2019). One is in surviving and growing in a competitive market for institutional funding and donations from individuals. This might provide pressure to simplify issues and overstate the impact that conscientious consumption campaigns have. Furthermore, NGOs sometimes compete with one another to be the most prominent certifier chosen by industry so as to have access to sensitive information and funding. As a consequence, NGO monitors face pressure to acquiesce to questionable industry practices. Such competition between agencies, such as the Program for the Endorsement of Forest Certification and the Forest Stewardship Council, is one mechanism that might degrade the quality of information reaching the consumer. Also, as in the corporate setting, agency problems arise: the individuals acting within the organization may be pursuing personal rather than organizational goals. This might entail sacrificing the ideals of the organization for short-term gains, such as being involved in a high-profile (but practically doubtful) standard-setting scheme (Bartley et al. 2015; Cafaggi and Renda 2012). ${ }^{14}$

Finally, a clear majority of the most prominent NGOs in the informational infrastructure are from developed rather than developing countries (Cafaggi and Renda 2012). It is not hard to see how perspective constraints might lead to developed-country biases in the selection of what constitutes grave flaws and judgments of their relative importance. For instance, Gay Seidman (2007) has traced how child labor and workplace safety form the main concerns of international NGOs monitoring the apparel industry, and violations of rights to organize are virtually ignored by the consumer-information infrastructure.

I believe the challenges facing individual consumers and the flawed informational infrastructure are enough to suggest that consumers are in a position of significant uncertainty. To illustrate my point, and to explore the extent to which even the best organizations might be of only minor help to conscientious consumers, I want to investigate the two supposed paradigm cases of consumer knowledge on which Hassoun relies: goods from organizations accredited by the WRC and by Fairtrade.

\footnotetext{
${ }^{14}$ Can the intelligence of international organizations such as the World Trade Organization (WTO) and International Labour Organization (ILO) assist the information infrastructure in determining which goods are pure and which are tainted? The prospects look doubtful. The WTO does not routinely monitor supply chains for moral flaws; it only does so if there is a dispute about barriers to trade, and there have been only a few such disputes. The ILO does have more remit to propose labor standards (as it has done), but like most international bodies, its fundamental role is coordination and best-practice information sharing. Given the consensus needed for international law and the contentiousness questions about whether developed countries are too eager to lean on labor concerns as "disguised protectionism," the ILO lacks the power or legitimacy to enforce, or even in most cases appropriately investigate, proposed labor standards violations (Hyde 2009). But even if the WTO or ILO had (or could have) significant intelligence about which products were tainted and which were pure, consumers would still need to be able to ascertain that this was a reliable source. It's not obvious that they could do so adequately for the great range of products they consume. I thank an anonymous reviewer for pressing this concern.
} 


\subsection{Example 1: The Worker Rights Consortium}

Let us begin with the WRC. This NGO aims to "document and combat sweatshop conditions, identify and expose the practices of global brands and retailers that perpetuate labor rights abuses; and protect the rights of workers who make apparel and other products" (Worker Rights Consortium, n.d.-a). The WRC has managed to remain surprisingly independent of the large manufacturers. Forty-five percent of its income comes from association fees from affiliated universities (Worker Rights Consortium, n.d.-b). The WRC operates in two main ways. One is by joining with pressure group United Students against Sweatshops to encourage universities to incorporate specific requirements for beyond-compliance codes of conduct (hereafter "codes") on the part of the university's merchandisers (e.g., Nike, Under Armour, Badger) who source product from suppliers in developing countries. The other is investigating claims by workers that conditions in supplier factories are substandard and communicating those investigations to the public and their university affiliates. ${ }^{15}$ Hassoun $(2019,40$ n17) thus claims that consumers can "promote positive change" by "boycotting university branded items" unless the university affiliates with the WRC. But this policy ignores the threat of significant uncertainty about provenance of goods, the effectiveness of consumer action, and the gravity of flaws.

First, consider mistakes about provenance. WRC affiliation provides no guarantee that any given university has successfully implemented WRC-approved codes in its licensing agreements with merchandisers, because universities are only obliged to "work toward" incorporating such codes in their licensing agreements. And even if universities were able to pressure merchandisers to adopt WRC-approved codes, it is possible or even likely that this would occur throughout the supply chain. Thus the same merchandiser's goods sold at non-WRC universities, or even department stores, could be just as pure as goods from WRC-affiliated universities. Second, consider mistakes about effectiveness. Crucially, we do not know how the merchandisers' relationships with upstream suppliers are affected by adopting WRCapproved codes of conduct. Ideally, merchandisers will respond to violations of the WRC-approved code by engaging with the factory to improve situations for the workers. But a typical response is often to ignore the violations (to no effect) or simply to cancel contracts with the upstream supplier (leaving workers in developing countries unemployed and, arguably, in a worse situation than they would be under sweatshop conditions) (Locke 2013). ${ }^{16}$ Third are mistakes about the gravity of flaws. The WRC codes of conduct could be overly stringent. For example, is restricting a supplier's employees to a forty-eight-hour workweek (where local laws are more permissive) appropriate? Does it strike a good balance between the rights of individuals to enter into contracts and the social benefit of restrictions on mandatory

\footnotetext{
${ }^{15}$ Hassoun claims that, "unlike the WRC, the Fair Labor Association gives companies control over monitoring their own factories" (40), which might be taken to imply that the WRC has the power to enter factory sites and does so routinely. This implication is false. The WRC has no authority to enter factory sites and typically investigates by offsite interviews with workers, not with direct monitoring of factories.

${ }^{16}$ It might also lead to merchandisers avoiding the least developed countries, where low-wage work for the export sector is most desired.
} 
hours? If not, it could be causing a serious flaw, not remedying one. Most dramatically, the WRC advocates that universities insist that their merchandisers require that their suppliers pay a "living wage." However, Alta Gracia, the one apparel factory that pays what the WRC considers a living wage, has been unable to turn a profit, which does not promise long-term sustainable employment at a systemic level (Legrain 2019).

The first of Hassoun's paradigms of consumer certainty is much more complicated than it first appears. If buying from WRC-affiliated universities comes with some (opportunity) cost, it seems consumers are in a situation where their uncertainty about whether this is the better personal policy at least looks to approach significance.

\subsection{Example 2: Fair Trade}

Another part of the information infrastructure Hassoun suggests we should trust is Fair Trade. ${ }^{17}$ One of Fair Trade's core goals is to provide a more stable, fairer price to cooperatives and farmers for their agricultural goods. But Fair Trade aims to do more than just pay workers more; it aims to empower and educate individuals, to build strong communities, and to protect the environment in producing countries. But is it effective at reaching these goals? Are Fair Trade goods purer than non-Fair Trade goods? Hassoun claims that "we have good evidence" that "many Fair Trade programmes benefit poor farmers and sometimes larger communities." The qualifiers in Hassoun's statement raise many questions: How often do how many Fair Trade "programs" need to benefit poor farmers for Fair Trade goods to be purer than nonFair Trade goods? And is that enough to rule out buying non-Fair Trade goods and channeling the cavalier dividend saved to good causes? It seems we need expertise.

Hassoun cites as evidence of Fair Trade's benefits one working paper (Murray, Raynolds, and Taylor 2003), one peer-reviewed article (Bacon 2005), and one edited collection (Ruben 2008). As well as these cautious supporters of Fair Trade, there are numerous critics. These critics' objections involve significant detail but raise several concerns. Regarding the provenance of Fair Trade goods, investigative journalism has detailed cases that illustrate that Fair Trade certification is far from a guarantee of fair treatment of farmworkers (Weitzman 2006). More systematic approaches suggest that very little of the premium paid by the consumer actually reaches poor farmers (Griffiths 2012; De Janvry, McIntosh, and Sadoulet 2015; Booth and Whetstone 2007). Regarding their effect, Griffiths (2012) suggests that Fair Trade's criteria means a better deal for farmers in developing countries with stronger institutions who are already relatively better off than the worst-off farmers in the poorest countries, and Fair Trade's blanket ban on genetically modified organisms arguably sets back development of a key technology for coping with environmental problems.

\footnotetext{
${ }^{17}$ In 2011, Fair Trade USA split from Fair Trade International (over a dispute about whether plantations as well as small farms should be included) (Bartley et al. 2015). But Hassoun talks just of Fair Trade in general, so I follow her nomenclature.
} 
Putting aside the direct critics, literature reviews in major journals give only lukewarm support for the idea that Fair Trade makes a valuable difference to the lives of those it tries to help. For instance, in a 2008 review article, Ann Le Mare claims, "The actions of Fair Trade practitioners and organizations are complex and variable, with multiple outcomes with rather less of the certainty than is offered in some marketing portrayals of Fair Trade" (1938). Dragusanu, Giovannucci, and Nunn $(2014,234)$ give a slightly more sanguine assessment, claiming that "Fair Trade does achieve many of its intended goals, although on a comparatively modest scale relative to the size of national economies." Dragusanu and colleagues note further concerns, such as that the Fair Trade system is "opaque" and that there is some evidence that Fair Trade cooperatives are trusted less by workers than nonFair Trade cooperatives. This might lead to concern about the success of the kinds of community development that Fair Trade aims to promote.

Overall, it is plausible that a policy of purchasing Fair Trade goods might be an improvement on cavalier consumption, but, given the relatively minor benefits, it is certainly not obvious whether individuals wanting to remedy global inequality or poverty would be best placed choosing Fair Trade over conventional alternatives and channeling the cavalier dividend (in time and money) to worthy causes. We will investigate this issue further in section 5 .

I have thus far just sketched the empirical basis for the threat of significant uncertainty, both in general terms and with two examples that have been held up as paradigms by a prominent supporter of conscientious consumption. I take it that the uncertainty facing consumers is major enough at least to consider whether soldier on with conscientious consumption is a worthwhile personal policy, once we take the relative epistemic conditions of consumers and the possibility for consumption with relinquishment into account. That is to say, I think it plausible that the uncertainty facing consumers is significant. That said, the relative extent of consumers' uncertainty compared to other agents is a difficult and largely empirical matter, which I have only outlined here. But even if I have vastly overstated the extent of consumers' uncertainty, considering what relatively high levels of consumer uncertainty would mean is still an interesting hypothetical. You might think it applies to select markets or that it might increase in the future. In any case, we should consider what significant uncertainty might mean for the supposed ethical priority of conscientious consumption, which occupies the next three sections.

\section{DEONTOLOGICAL APPROACHES}

Deontological arguments focus on identifying morally troubling relationships, causal or otherwise, between individual conscientious consumption policies and the upstream grave flaws. This can be spelled out in different ways. For instance, one might hold that consumers should avoid becoming complicit in grave flaws, where complicity is the relationship of being a "core participant" in some practice (Schwartz 2010, 69-84). A deontologist might also warn against consumers involuntarily benefiting from injustice, especially when there is no good way to 
appropriately relinquish the benefit. ${ }^{18}$ Julia Nefsky (2018) suggests that even a single ineffectual purchase might fit the morally relevant relationship of "helping" to bring about a bad outcome in the future. Waheed Hussain, like Schwartz, takes the relevant moral relationship to be one of participating but adds a nuanced view of the nature of the obligation that results. Hussain (2012b) claims that participation in a typically morally legitimate institution (the market) is not wrong in itself, but it creates special remedial duties. Because of their participation, consumers should take on some of the enforcement roles governments are proving to be unable to play in global production networks by shunning tainted goods and selecting pure(r) goods. As well as different types of relationships, different versions of a deontological approach have two different levels of stringency. One might be strict, holding that any level of the appropriate wrong-making relationship creates overall moral reason to favor policies of shunning the relevant good. Another kind of approach might be relaxed, holding that there is overall moral reason to set shunning policies only when the wrong-making relationship becomes strong enough for the good to be judged "sufficiently tainted." Which of these approaches, if any, points to the priority of conscientious consumption?

\subsection{Strict Deontology}

Let us begin with the strict version, which sees any risk of being morally implicated in the grave flaws as morally unacceptable. Recall that significant uncertainty might recommend that agents avoid uncertainty by shunning whole domains. In section 1, we considered that the inaccuracy of her map coupled with concerns not to risk life and limb of her team could plausibly lead Obscured to avoid uncertainty by shunning crossing the land completely, even at significant cost. Analogously, a strict deontologist (call her Austere) might be tempted to avoid uncertainty through practicing or recommending "hyperlocal" conscientious personal policies. Austere's policies would aim at avoiding goods from global supply chains completely through purchasing only local items of known provenance. I believe this would be a mistake, even granting the strict deontological approach.

My argument cannot rest on the idea that a policy of complete withdrawal from global supply chains will be very costly for Austere (or those she would help, if the alternative is consumption with relinquishment). After all, the point of the strict deontological approach is that Austere should avoid being in a morally relevant relationship with the grave flaws, even if she could bring about more good through remaining in the relationship and spending the cavalier dividend wisely. Rather, my key objection is that, by avoiding uncertainty via hyperlocalism, Austere is more likely to enter similarly bad morally relevant relationships with grave flaws than if she were to practice consumption with relinquishment or cavalier consumption. ${ }^{19}$

\footnotetext{
${ }^{18}$ This avoid-benefiting-from-injustice argument can be found, with less than complete endorsement, in Schwartz (2010, 82), and Lawford-Smith (2015) thinks it interacts with other duties. See also Pasternak (2016), Butt (2007), and Kingston (2020).

${ }^{19}$ Note that some try to make an argument for hyperlocalism on independent environmental grounds, but these arguments are usually flawed by not taking into account comparative environmental advantages of trade
} 
Consider the credible claims made by economists and the World Bank that, because countries seek to produce according to their comparative advantage, international trade provides benefits for developing as well as developed countries, however unequally those benefits might be currently shared. ${ }^{20}$ Even if one is less confident than these experts that global trade is a net benefit for the global poor, it hard to deny that it is a system on which millions of the world's poorest have come to rely and around which they have formed legitimate expectations. Thus it is reasonable to expect that the effect of existing movements of consumers shunning global supply chains would foreseeably be to set back the interests of many of the vulnerable global poor. This means, I argue, that the same kinds of strict deontological concerns that count in favor of hyperlocalism also would count against hyperlocalism. By avoiding uncertainty through hyperlocal consumption, Austere participates in/benefits from/helps the cancellation of mutually beneficial trading arrangements on which the global poor have come to rely.

A strict deontological defender of hyperlocalism might try to rescue Austere's policy in two ways. One way would be to offer a double-effect defense. Deontological approaches often can ignore the costs of some action if they are merely foreseen, not intended. Because Austere does not intend to set back the interests of the vulnerable global poor, she would be off the hook for that consequence. Another way would be to offer the inefficacy defense, claiming that Austere should be concerned with the actual quality of her policy and not the aggregate effect of many people following a similar policy.

Both defenses rescue the hyperlocalist version of conscientious consumption but suggest that cavalier consumption and consumption with relinquishment are also both permissible. The double-effect defense would allow Austere to practice cavalier consumption, for the bad effects that flow from cavalier consumption are also unintended (unless someone purchases tropical wood, say, in order to destroy Indonesian rainforest!). The same argument applies to consumption with relinquishment a fortiori, because the benefits to the global poor are intended, whereas the harms are not. The inefficacy defense strays even further from hyperlocalism as a response to significant uncertainty. By claiming that Austere can set a policy of shunning goods from global supply chains because the effect on the livelihoods of the global poor is negligible, the strict deontologist is granting too much. She grants that it is ultimately the consequences of a policy, not the noncausal relationship that the policy has to the grave flaw, that matter morally. And if a policy of shunning all goods from global supply chains has only a negligible effect, consistency would suggest that the effect of her following a cavalier or relinquishment policy on the grave flaws would also be negligible. Again, the inefficacy defense, if it allows

\footnotetext{
and assume the costs of transporting goods must be high, when transport by container ship and rail is often very efficient (European Chemical Transport Association 2011).

${ }^{20}$ The voluminous work supporting this idea begins with Adam Smith ([1776] 2003). A key empirical work is Frankel and Romer (1999). For the World Bank position, see https://www.worldbank.org/en/topic/ trade/overview.
} 
would-be conscientious consumers to practice hyperlocalism, also allows them to practice cavalier consumption.

Assuming the strict deontologist does not use the inefficacy or double-effect defense, she is left in a quandary about what to recommend in the light of significant uncertainty. One shouldn't soldier on, blunder blind, or delegate tasks, because these policies all come with a nonzero risk of being implicated in grave flaws, but one shouldn't avoid uncertainty via hyperlocalism either, because this would implicate one in severing mutually beneficial relationships with the global poor. A consistent strict deontologist sees us all as featuring in a tragic dilemma, where we cannot help but do wrong. If that is the case, it seems plausible that choosing the practice has the best consequences would be a good way to break a supposed moral tie. I argue later that consumption with relinquishment is typically the practice with the best consequences. ${ }^{21}$ In any case, even a tie between consumption with relinquishment and conscientious consumption is a remarkable conclusion: a moral requirement to keep very clean hands, in light of the significant uncertainty of consumers, actually supports the ethical adequacy of relinquishment.

\subsection{The Relaxed Deontological Approach}

Let us turn now to the relaxed version, in which moral reasons are triggered by some threshold at which goods are judged sufficiently tainted to require shunning. One might be tempted to conclude that this approach would recommend soldiering on in the case of significant uncertainty. This is how such reasoning might go:

Given our ignorance, our conscientious consumption policies will probably cause us to act on false negatives, to purchase some goods we should have judged to be tainted. Despite this, conscientious consumption policies will still be acceptable. For on the relaxed deontological account, there is already a level of arbitrariness in deciding which goods count as sufficiently tainted and which count as sufficiently pure. This means that recognizing false negatives is not fatal to the strategy of soldiering on with conscientious consumption policies. ${ }^{22}$

But, we should ask, what would encourage us to judge such a strategy of soldiering on permissible, as opposed to aiming for clean hands by avoiding uncertainty? One answer is that such approaches tolerate some false negatives to a level that is outweighed by the benefits of avoiding the huge numbers of false positives (treating pure products as tainted) that a policy like Austere's would produce. But this means that the relaxed deontologist argument for soldiering on in the light of significant uncertainty is not a deontological approach at all but a version of a consequentialist

\footnotetext{
${ }^{21}$ Brock (2014) and Calder (2010) make an insightful objection to a hyperlocalist strategy on some deontological grounds. These authors point out that, at least if the morally relevant relationship between consumers and the upstream flaws is one of benefiting from injustice, this probably also holds between those who practice global shunning and the upstream flaws. This is due to shunners benefiting indirectly, for example, from the cheaper consumer goods available to others in their communities. Because this approach relies on one particular moral relationship (benefiting from injustice), I do not discuss it further here.

${ }^{22}$ See Andreou (2006) for the arbitrariness of the relaxed deontological approach.
} 
approach, so we can discuss its plausibility in section 5. Suppose, alternatively, that the reason this balancing of false positives with false negatives is tolerable is that it represents the appropriate attitude to hold toward the potential victims of grave flaws under uncertainty. That is to say, a policy <buy only Fair Trade coffee $>$ might mean one participates in/helps/benefits (from) a worse deal for developing world farmers but the balance of risks suggests that this kind of policy still represents an appropriate level of respect to those farmers. But while appropriate respect might justify conscientious consumption in this way, it also might justify consumption with relinquishment, because that arguably also demonstrates an appropriate respect toward those living in countries where the grave flaws are rife. If the relaxed version of the deontological approach does not collapse into consequentialism, it seems to provide no general reason to choose conscientious consumption over consumption with relinquishment, and thus the adequacy of relinquishment is supported.

\subsection{The Duty-of-Preservation Approach}

The final type of deontological approach we will consider draws on the idea that consumers, by having participated in the market, gain a duty to preserve its legitimacy. For Waheed Hussain (2012b, 2018), the justification for conscientious consumption comes not from a duty to keep one's own hands clean but from a duty to repair a broken but still potentially morally legitimate system in which one is a participant. Hussain holds that all downstream actors need to "step up" to fill the responsibility deficit that plagues global supply chains. This much the supporter of consumption with relinquishment can go along with, for it only indicates a morally relevant relationship (that of participating in a morally legitimate system in need of repair) that might attach to consumers. The practical upshot for Hussain (2012b, 171 ) is that this duty entails a moral requirement for consumers in general to "keep up with a variety of certification schemes" and to "pressure and shame other market actors." Hussain (2018) makes it clear that the reason behind this duty is, temporarily at least, to supply the enforcement powers that international standard-setting bodies like the International Labour Organization lack.

Once again, these conscientious consumption policies might be completely plausible under conditions of adequate certainty. If, alternatively, consumers suffer significant uncertainty about the provenance of products, the effect of selecting or shunning, and the gravity of upstream flaws, what follows? Here the rival strategy to soldiering on is not to avoid uncertainty but to delegate tasks. Just as Obscured might respond to significant uncertainty by assigning the task of mine clearing to a rearguard with better equipment, consumers might respond to a poorly regulated global market by blundering blindly and passing the cavalier dividend on to those better placed to preserve the moral legitimacy of the global market in consumer goods.

One might wonder, if the main concern about global supply chains stems from the deficit in regulation of the global marketplace, which other players can take up that role? I believe the field of potential agents of change is richer than is often understood. Most immediately, as Hussain (2018) acknowledges, the task of providing 
incentives to firms to avoid causing global flaws might be provided by other downstream market actors. ${ }^{23}$ Perhaps most controversially, conscientious investors might seek out companies with a social impact that reduces the grave flaws; shun companies that fall below some threshold of decent behavior; or engage with them by using, for example, proxy resolutions. ${ }^{24}$ Workers in downstream firms can not only also try to influence their own firms' policies from within but incentivize good conduct by allowing concerns about grave flaws to determine their decisions about if and when to leave or join firms. ${ }^{25}$

But more radically, consumers could channel their cavalier dividends in time, money, and personal energy to actors outside the market. Some of these actors might be at the grassroots level-these might include transnational efforts to bolster workers' rights to organize (Ronzoni 2016) as well as to support legal and political expressions of popular sovereignty brought against countries accused of violating human rights law. ${ }^{26}$ At the institutional level, there are promising proposals at the academic stage that point out ways states could reform the opaque investor-state dispute settlement system, which many claim prevents developing countries from enacting stronger regulations protecting environmental, labor, and social concerns (Eberhardt and Olivet 2018; Slater 2015). More ambitiously, there are proposals to create a democratic, transparent way to improve global labor standards without penalizing poor countries (Barry and Reddy 2008). Finally, NGO-led citizens' campaigns could pressure their own countries to enact domestic policies that help reduce grave flaws abroad, such as ending farm subsidies, contributing more support to burgeoning regulatory states in developing countries, or clarifying to the judiciary that countries headquartered there can be held liable for violations of human rights abroad (Ruggie 2013; Schrempf-Stirling and Wettstein 2017).

I argue that, of the different aforementioned actors who might take up the task of providing remedies to grave flaws in global supply chains, consumers are typically in the worst epistemic position, for three reasons. First, consumers are epistemically further from the grave flaws than other potential actors. Conscientious job seekers and a fortiori conscientious job leavers, as well as conscientious investors in downstream firms, are at least one step closer in the supply chain to the flaws in question. Outside the market, grassroots campaigns are by definition much closer to the flaw in question. Diplomats of developed-country governments will typically have more

\footnotetext{
${ }^{23}$ The task of transferring the cavalier dividend to these groups is especially easy when it is the same individual who plays both these roles, but resources and support can be transferred around our personal networks to assist others if we ourselves are neither workers in relevant industries nor investors.

${ }^{24}$ See Vogel (2007) and Sandberg (2013) for a critical look at the efficacy of ethical investing.

${ }^{25}$ In particular, there is concern in the fossil fuel extraction industry that they won't be able to attract talented young professionals to replace the retiring generation of baby boomers. For instance, when Norwegian state-owned enterprise Statoil recently changed its name to Equinor, the CEO cited the need to "arouse curiosity among young people so they see the other aspects of Statoil, including renewable energy" (Adomaitis 2018). For data on the relative importance of the "ethical reputation" of firms for Millennial and Gen Z job seekers, see Deloitte (2018).

${ }^{26}$ See the work of Earthrights International (https://earthrights.org/about/) and Advocates for Alternatives (https://advocatesforalternatives.org/about-us/).
} 
experience with, and understand better, the needs of developing countries, and domestic campaigns for institutional reforms have more ability to seek direct input from developing-country perspectives than unorganized consumers do. Consumers seem to have no advantage over any of these actors, epistemically speaking. Second, remember a disadvantage of consumers: the wide range of options. Because each consumer is connected to so many supply chains, the range of issues about which consumers must know spans industries, sectors, global regions, and grave flaws. By contrast, most employees and some investors are involved in a far more limited number of supply chains, which enables a natural division of epistemic labor. Conscientious workers and investors have independent incentives to learn in depth about a few domains in the vast world of global supply chains. Governments and many NGOs have a wide scope of concern, but division of labor within institutions allows for specialization. Third, the root reason preventing consumers from meeting the challenge of the wide range of options and their distance from the grave flaws, as well as specific epistemic challenges, is the lack of organization among consumers. Consumers are, by and large, an unstructured group — not generally organized in the right kinds of ways to collate and process large amounts of information-whereas, for instance, workers within firms or labor unions already have some institutional structure. ${ }^{27}$ These reasons suggest that, in light of significant uncertainty, the dutyof-preservation view provides moral reasons that support blundering blindly in the market while delegating tasks and using the cavalier dividend to support those granted with the tasks.

Perhaps, a proponent of ethical consumerism might argue, some wisdom-of-thecrowds effect might make consumers as an unstructured group wiser than they seem. Just as diverse sets of problem solvers do better than teams of experts, and an average of untutored predictions can often exceed expert judgment, the aggregate of consumers can outperform other agents at remedying grave flaws (Hong and Page 2004, 2012; Page 2008). The problem with this argument is that the theoretical results on which the wisdom-of-the-crowds literature builds (e.g., Hong and Page 2004) apply, in the case of problem solving, to groups of problem solvers applying diverse heuristics to particular kinds of difficult problems with 1) multiple local optima, 2) consensus about relative success conditions, and 3) clear feedback about whether attempts meet those conditions (Page 2008). This does not describe the problem of remedying grave flaws very well at all, especially given significant uncertainty. ${ }^{28}$

In sum, none of the deontological approaches we have discussed result in the priority of conscientious consumption, and thus the adequacy of relinquishment

\footnotetext{
${ }^{27}$ It's true that there are consumer collectives. There are formal collectives aimed at protecting consumer rights and interests, and groups of aficionados, but they are bound by a common thread between the members - a passion, a shared local community. Even if consumers interested in remedying some grave flaw form a community, they need more than such a specific interest to form a functioning collective.

${ }^{28}$ The case of the "wisdom of the crowds" in prediction seems even further removed from the task of remedying grave flaws in global supply chains since the predictions on which the collective wisdom models are based are easily quantified predictions (such as the weight of a steer or the location of a submarine) (Hong and Page 2012).
} 
thesis is supported. I argued that the epistemic situation of consumers compared to other potential agents of change is relatively poor, which counts against the duty-ofpreservation argument for conscientious consumption. A relaxed version of a "standard" deontological approach (that consumers should avoid morally relevant [noncausal] relationships with grave flaws) either gives no independent support to conscientious consumption over consumption with relinquishment or is fundamentally sensitive to the consequences of different practices. I also argued that the strict version of the deontological approach must conclude that consumers are in a tragic dilemma between bad options. However, I suggested that in such a situation, aiming at the bad option with best consequences is commendable. So far, I have merely asserted that consumption with relinquishment (blundering blindly but using the cavalier dividend wisely) is the practice with the best consequences. In what follows, I back up that assertion, which will be of independent interest to many, as it concerns the consequences of different consumption practices.

\section{CONSEQUENTIALIST APPROACHES}

Can consequentialist approaches support the priority of conscientious consumption? That is to say, can they show that an individual practicing conscientious consumption produces significantly better expected consequences overall compared to available alternatives? ${ }^{29}$ There will be great differences in consequentialist approaches regarding what the morally relevant consequences are. For instance, while utilitarian versions might support those consumption policies that best promote overall wellbeing, sophisticated consequentialist views would suggest that individuals choose those consumption policies that best promote, for instance, individuals' rights or the beauty of ecosystems. For initial purposes, we can consider both utilitarian approaches and sophisticated consequentialist views together.

\subsection{Upstream Effects}

One might be tempted to think that the biggest challenge facing such consequentialist accounts is to show how this kind of approach can issue in overall moral reason for an individual consumer to set conscientious policies even given certainty about provenance of products, the gravity of a flaw, and the effect of masses of consumers shifting consumption. After all, the consumption patterns that incentivize morally flawed upstream processes seem to be essentially aggregate-level phenomena. However, there are good consequentialist accounts that draw out the moral relationship between an individual act of purchase and the aggregate effect of incentivizing grave flaws. Shelley Kagan (2011), Alistair Norcross (2004), and David Schwartz (2010) argue that while purchases have a large chance of triggering nothing at all morally significant, they have a minuscule chance of triggering some significant market threshold or social threshold. The rough heuristic that results is that the effect

\footnotetext{
${ }^{29}$ Some consequentialist views would hold that the question concerns what the actual effects of a policy are, not what the expected effects are. My response to such approaches will mirror my response to focusing on objective moral reasons (see note 4 ).
} 
of a single act (or, in my case, policy) is some large effect of reducing a grave flaw multiplied by the very small chance that it is the act (or policy) that makes a difference. While those views garner some criticism, ${ }^{30}$ such consequentialist approaches are potentially viable as explanations of at least the expected value that an individual purchase has regarding the grave flaws.

So, putting aside the worry that individual consumer policies bring about no benefits in terms of reducing grave flaws, what can we say about the upstream net effect of global supply chain conscientious consumption policies in the aggregate? Consequentialists must leave it open that this effect could even be negative. As well as the criticisms we have made of Fair Trade and the WRC, consider some of the highestprofile cases of conscientious consumption, such as shunning soccer balls unless they are certified by UNICEF not to have been sewn using child labor or avoiding conflict minerals from the DRC. These have been determined by some analysts to have exacerbated the problems they were designed to solve (Parker, Aragon, and Parker 2017; Cadot, Traca, and Crawford 2001; Hyde 2006). In fact, to a skeptical eye, it is much easier to find cases of conscientious consumption causing harm upstream than causing a benefit upstream. But I do not want to rest my case for conscientious consumption on the claim that it creates more harm than benefit. Assume that there is some benefit caused by aggregate demand for what appear to be purer goods and that the expected value of individual conscientious consumption policies are some (tiny) fraction of that benefit. Even then, it is not obvious that conscientious consumption practices are better than consumption with relinquishment.

\subsection{Downstream Effects}

Along with upstream costs and benefits, conscientious consumption has downstream costs borne and benefits received by the consumer and those with whom he or she interacts. The first kind of downstream cost is the increased monetary cost to the consumer. Typically, apparently purer goods come at a premium. With fair-trade coffee, for instance, the differences between what retailers would have charged for the same coffee without the Fair Trade certification are both counterfactual and confidential. Some estimates are an extra ten British pence per cup or five US dollars per pound of coffee, via retail (Griffiths 2012).

This problem arises a fortiori for those clean items that have a larger markup compared to their substitutes. And many (if not most) apparently pure(r) items are in this category. For instance, Fairphone (n.d.) produces a smartphone that actively tries to "support economic development and encourage responsible mining practices in the DRC and beyond" by "partnering with a variety of initiatives to set up transparent supply chains for the essential minerals used in our phones." Even if we take at face value Fairphone's claims to have found good-quality sources of 3TG from within conflict areas, the trouble is that such a phone is more expensive by a

\footnotetext{
${ }^{30}$ See Nefsky (2011). Budolfson (2019) and Chartier (2006) argue that, in many supply chains containing epistemic lag as well as supply inelasticity, the Kagan-Norcross-Schwartz approach overestimates the impact of an individual purchase.
} 
factor of two than another phone of comparable quality (Cahalane 2015). This level of markup for pure goods is not unusual. Internal research by Ethical Consumer measured the typical cost increase between the products with its top-three rating in a category and the products with its bottom-three rating. Ethical Consumer found that this varied significantly by category of goods, from a 900 percent markup for the toprated shampoos to a 150 percent markup for the top-rated apparel, with a few categories, such as top-rated refrigerators and sunscreens, being cheaper than the alternatives (Pooler and Harrison, n.d.). Note that these figures do not take into account that Ethical Consumer compares brand-name items, not unbranded items or store-brand items, which would only increase the markup for apparently purer products.

It might seem gauche (or even just wrong, in a rights-based consequentialist approach) to compare a few dollars saved by buying a dirty product to the potential expected benefit of a purer purchase reducing or remedying the incidence of grave flaws like banditry, the worst forms of child labor, or deforestation upstream. But we need to remember that our contrast class does not contain only cavalier consumption, where that money saved could be spent on anything. When we contrast the net effect of conscientious policies with the net effect of consumption with relinquishment, the increased downstream cost of conscientious consumption appears highly relevant. Every dollar spent on making sure one's chocolate bar is pure with regard to bonded child labor is a dollar that could have been spent trying to improve overall welfare in a more effective way under utilitarian considerations or remedying the specific kind of grave flaw in other ways (as sophisticated consequentialist approaches would suggest). The increased time and energy spent researching pure alternatives to dirty goods, and obtaining them, also must be assessed as part of the relevant cost of a conscientious consumption policy.

Apart from the costs directly borne by the consumer in question, there can be less obvious downstream costs. One might argue that an individual practicing conscientious consumption will lead to moral licensing, making it less likely that an individual consumer will behave morally in general after buying a cleaner product. The moral self-licensing effect appears in studies about political consumerism in particular. In one experiment, consumers randomly assigned to buy goods from an online store with environmental credentials were more likely to lie and steal immediately afterward than those assigned to buy from a conventional store (Mazar and Zhong 2010). Perhaps even more concerning, participants in one study who were simply given an organic cotton towel as a reward were less likely to subsequently donate money to help refugees than those given a conventional towel (Engel and Szech 2020). Of course, it is unclear to what extent these studies have external validity and demonstrate a persistent moral self-licensing effect that applies specifically to conscientious consumption (and not, say, consumption with relinquishment), but they might give advocates of conscientious consumerism pause. ${ }^{31}$

\footnotetext{
${ }^{31}$ One might wonder whether this criticism is unfair: don't all moral actions risk moral licensing to some extent? One reason to think that moral licensing applies more strongly to conscientious consumption is the tangible, physical reminder of one's "pure" purchase. I thank Allen Buchanan for raising this worry.
} 
Is there potential, though, for conscientious consumption to have side effects that are significantly positive? The apparently purer good might be (or appear to be) more pleasing to the consumer, as when a consumer finds fair-trade coffee tastier than his or her usual brand. ${ }^{32}$ But even if this is a consistent effect, some sophisticated consequentialists will not count consumer pleasure as a relevant effect. However, consequentialists of all stripes might think that if conscientious consumption policies also increase political engagement with remedies of the grave flaws, this would be a relevant benefit of conscientious consumption. As consumers seek to choose cleaner products, this story goes, they become more aware of the extent of the grave flaws, the complexity of the situation, and possibly actions that state actors or NGOs might take to remedy the grave flaws in a more systematic way.

This is true, but the effect of conscientious consumption on political engagement might also be negative. Consider a political version of the moral licensing worry presented earlier (call it political licensing). Because consumers might feel that they have "done their bit" for, say, remedying deforestation by buying Forest Stewardship Council-certified deck furniture, they might be less motivated to, say, support attempts to prevent global deforestation on the agenda of their countries' legislatures or executive branches. It's worth noting that conscientious consumption might be a more tempting avenue than conventional political activism: unlike attending a rally, it can be practiced largely on one's own schedule, and unlike writing to a political representative, it can often be easily displayed publicly and thus double as conspicuous consumption or virtue signaling (Heath and Potter 2004). ${ }^{33}$ Furthermore, the kinds of research that a consumer needs to do to assess a product's provenance typically removes the consumer from considerations of the deep structural causes of a grave flaw, for the necessary research often concerns the impartiality of various elements of the infrastructure or histories of retail companies, rather than focusing on issues like the barriers to enforcing regulatory rules in the upstream country or the level of international support a nascent upstream regulatory state gets. Contrast this with a consumption with relinquishment approach, in which upstream considerations of what works to reduce grave flaws on the ground will typically be paramount.

I have found just two empirical studies of the issue of the interaction between conscientious consumption and political action, both with inconclusive results. Margaret Willis and Juliet Schor (2012) analyzed the results of two US nationwide surveys and found some correlation among American adults between rates of conscientious consumption and political engagement in general. But as Willis and Schor admit, their cross-sectional data could not show a causal effect of

\footnotetext{
${ }^{32}$ I thank an anonymous reviewer for this example.

${ }^{33}$ See O'Rourke $(2012,79)$. Barry and Macdonald $(2016,102)$ claim that "there is a great deal of evidence" that political consumerism campaigns and corporate accountability campaigns have "evolved in complementary and mutually supportive ways." But the evidence they cite only involves ad hoc measures, such as downstream Fair Trade consumers also receiving, for example, school visits from upstream producers or information about broader campaigns to "make Trade Fair" rather than data as to the level of effective engagement that consumers take on global trade justice.
} 
conscientious consumption on political engagement. Furthermore, four out of five respondents in one of the surveys reported becoming politically active before practicing conscientious consumption, so a "gateway" effect seems unlikely. ${ }^{34}$ Another empirical study of Dutch-speaking Belgians did find marginally significant results that engaging in conscientious consumption during 2017 was correlated with slight increases in political engagement during 2018 (De Moor and Verhaegen 2020). Neither survey was precise enough to show a strong connection between the domains in which conscientious consumption was practiced and the types of political engagement the individuals undertook. Given the paucity of good data on this issue, it seems premature to include potential effects of synergistic effects, positive or negative, in the consequentialist analysis of conscientious consumption.

\subsection{The Upshot for Consequentialists}

We have surveyed some of the main proposed direct and indirect costs and benefits of conscientious consumption. How does significant uncertainty interact with the cost-benefit payoff for the consequentialist?

Return to the analogy of Obscured's mine field. As uncertainty about the map's accuracy increases, the expected value of trying to demine or avoid a mine in any particular spot drops, while the cost of actually receiving and consulting the maps remains relatively constant. Thus the expected value of soldiering on, trying to use the map to cross or demine the field, lessens simply as a function of how bad the map is and can drop below the expected value of blundering blind. When the expected value of using the map is overall worse than an alternative like blundering blind and using the time and resources saved to good use, consequentialist approaches support doing away with the map.

For utilitarians, the cost of checking the easily available consumer-information infrastructure and following its directions will remain relatively constant regardless of uncertainty about its accuracy, and efforts by an individual to further reduce uncertainty, to increase the expected value of his or her purchase, will also be costly in terms of time. There might be synergistic benefits to political movements of individuals trying to improve their knowledge, but there is also reason to suggest that conscientious consumption has a distracting or undermining effect on political action in the relevant domains. All in all, at least on a utilitarian account, the oftneglected cavalier dividend combined with significant uncertainty greatly worsens the expected value of conscientious consumption. Of course, we should remain open to good evidence to the contrary, but given what appears to be the relatively low cost of increasing utility dramatically in developed countries through charitable giving, ${ }^{35}$

\footnotetext{
${ }^{34}$ As Bartley et al. $(2015,80)$ point out, any correlation could also be the result of conscientious consumption and political consumption overlapping: "It is possible that . . consumer activities expand and political activities subsequently contract. In other words, the crowding-out effect could take hold as individuals progress through their lives or as larger historical changes shape the distribution of different forms of engagement."

${ }^{35}$ Effective altruist organizations estimate the cost of saving a life or an equivalent benefit in developing countries as a few thousand dollars (Givewell 2016).
} 
it is hard for me to see how utilitarian approaches would support the priority of conscientious consumption across the board.

Perhaps low-hanging-fruit policies of choosing an apparently pure option when it is cheaper or on par with the apparently tainted option (e.g., shunning or selecting a particular major gasoline retailer due to news reports about recent poor conduct) could be justified by the consequences. Even then, if moral or political licensing effects are strong, even such low-hanging-fruit policies might not be justifiable on conscientious consumption grounds.

Things might seem to be a little more complex for a sophisticated consequentialist who places great negative weight on, for example, violations of rights to bodily autonomy or to property. Such an account would still recognize our tainted purchases as contributions to grave flaws, such as forced labor or banditry, but refuse to measure the cavalier dividend by the utility it could produce via highly effective charities. Wouldn't such an account support a more robust conscientious consumption policy than the mere low-hanging-fruit policies? To answer this, we must keep in mind that the relevant alternative to conscientious consumption need not be a practice of consumption with "wide" relinquishment that simply tries to offset the damage done by grave flaws in global supply chains to which one contributes. Rather, relinquishment can be targeted in that it can channel the cavalier dividend to specific actors who work to remedy upstream harms, perhaps like those we surveyed in our discussion of the duty of preservation in section 4.3. It might be impossible to prevent the very acts of forced labor from which I am probably benefiting by buying new clothing from global supply chains. However, the sophisticated consequentialist could still use the cavalier dividend to support efforts to strengthen institutions that aim at seriously reducing the incidence of forced labor. These might include international human rights NGOs or campaigns for domestic politicians who have pledged to tackle such issues on either a domestic or global scale. In all, neither a utilitarian nor a more sophisticated consequentialist approach supports the priority of conscientious consumption. Rather, they support the ethical adequacy of consumption with relinquishment.

\subsection{An Epistemic Objection to Consumption with Relinquishment and a Reply}

My consequentialist-based epistemic argument against the priority of conscientious consumption relies on the contrast with consumption with relinquishment. Some might worry that the same problems of significant uncertainty simply reappear at the level in which someone is trying to spend the cavalier dividend that is derived by eschewing conscientious consumption. This is exacerbated for the approaches that place great value on specifically reducing grave flaws, because they cannot rely on the existing infrastructure of how best to promote human welfare. ${ }^{36}$

\footnotetext{
${ }^{36}$ A further problem is uncertainty about the size of the cavalier dividend. Systematic thinking about this might be difficult, as the baseline is the cost of the conscientious consumption policy one would have chosen in the absence of systemic ignorance. Self-interest in wanting to minimize the amount one is obligated to donate, as well as the lack of an objective measure of the cavalier dividend, could well lead consumers to underestimate its size. I discuss this in Kingston (2020).
} 
My answer here parallels the epistemic advantages of other ways of responding to the grave flaws. Depending on one's version of consequentialism, one could focus on trying to spend the cavalier dividend on just one kind of grave flaw, and one way of remedying it, or at most a few, making the payoff for time spent researching the issue in depth much more worthwhile than if one were to try to trace the relationship between what one buys and the wide range of grave flaws to which each product might be linked. Although the information infrastructure facing someone wishing to spend the cavalier divided will also feature many of the structural problems that plague the conscientious consumer, specialization will help such consumers understand the information infrastructure and its strengths and weaknesses. The consequentialist argument for the adequacy of relinquishment is strong.

\section{A NOTE ON CHARACTER}

What about those defenses of conscientious consumption that begin from the importance of moral character? Conscientious consumption is sometimes supposed to demonstrate virtues, such as care, empathy, solidarity, and fair-mindedness. But for virtue theory to recommend soldiering on with conscientious consumption in the face of significant uncertainty, we need to know that these virtues still apply. After all, in light of significant uncertainty, compared to consumption with relinquishment, conscientious consumption policies might instead embody hubris or obstinacy. To return to our example, if Obscured had a very good map, asking her team to demine the fields certainly might demonstrate care, empathy, solidarity, or fairmindedness. If her map was very poor, the same strategy might now express the opposite due to risks it poses to her team. Likewise, conscientious consumption only truly embodies care, empathy, solidarity, or fair-mindedness if they represent an appropriate way of helping those one should be helping or treating fairly. Consumer uncertainty, I argued earlier, is highly prevalent. I believe that my arguments in sections 4 and 5 show that conscientious consumption is an inappropriate way to help the most vulnerable and deserving, and so typically, it is consumption with relinquishment that is a true embodiment of care, empathy, solidarity, and fairmindedness. At the least, I have yet to see virtue-ethical defenses of conscientious consumption that take significant uncertainty and consumption with relinquishment into account. The adequacy of relinquishment thesis does not seem threatened by virtue-ethical approaches.

\section{CONCLUSION}

I have argued that the ethical priority of conscientious consumption looks far less plausible once we consider two often overlooked factors. One factor is that alternatives we should consider are not just consumers blundering through the market blind to upstream ethical concerns but consumers doing so and giving away the resources they save by not shopping their values. The other is the significant uncertainty that plagues consumers in particular, to a greater extent than workers and investors and more than NGOs and government departments. Taking these factors into account 
affects different kinds of consequentialist and deontological reasoning in different ways but at best recommends only low-hanging-fruit policies that do not pose significant costs in terms of time, money, and motivation. In general, the adequacy of relinquishment thesis appears well supported.

I should point out here a number of limits of this current work. I have not considered a conditional argument for conscientious consumption on the grounds of integrity. For instance, one could argue that if one can be a more effective agent of political change by publicly appearing to consume conscientiously, then one should do so. And there is some evidence for the truth of the antecedent in some domains (Attari, Krantz, and Weber 2019). Also, whereas I suggest that even those taking a rights-based consequentialist view would largely support consumption with relinquishment, channeling the saved resources into promoting institutional change, strategic, targeted boycotts on whole countries to support or promote institutional changes might escape some of the epistemic problems I outline (see, e.g., Wenar 2016, 281-313). I have also focused on one of the domains of conscientious consumption (reactions to grave flaws in global supply chains) where significant uncertainty looms large. My analysis will apply less well to various other cases of conscientious consumption. For instance, in the case of conscientious consumption campaigns against local firms with bad production practices, consumers will have direct epistemic access to the production process. In the case of boycotts of goods from a particular country, country-of-origin labeling (unlike the certification of absence of upstream flaws) is institutionalized, so the provenance of at least simple commodities can be identified accurately. ${ }^{37}$ (Of course, such boycotts raise their own ethical questions aside from epistemic issues.) And in the case of obvious malfeasance by downstream companies where they are headquartered (rather than upstream), the distance between consumers and the purported grave flaw is less, so my epistemic arguments against conscientious consumption in global supply chains might not extend to these kinds of conscientious consumption.

Whether the domestic agriculture industry is marked by significant uncertainty of consumers is also a complex question. How different food choices affect water, soil health, pollinators, carbon emissions, and so on is hard to ascertain, even for experts. Eating beans instead of grain-fed beef might be a clear environmentally beneficial choice in most circumstances, but apart from that, much is deeply unclear about the environmental effects of food choices (Harwatt et al. 2017). While some small-scale agriculture systems, such as permaculture or regenerative agriculture, seem less clearly linked to grave flaws, whether they can be scaled up is debatable. Organic certification certainly does not track purity with regard to environmental grave flaws (Szasz 2007), and neither does a plant-based diet. For instance, a vegan diet high in methanogenic wet-paddy rice might have a larger carbon footprint than a rice-free diet incorporating chicken and eggs (Budolfson 2015). Fundamentally, consumers are largely in the dark about which food choices are better for the environment and

\footnotetext{
${ }^{37}$ Region of origin as a proxy for production processes was used in this way in the British abolitionist sugar boycott (Hochschild 2006).
} 
other humans. Thus much of my analysis of consumer practices regarding grave flaws in global supply chains might also apply to environmental flaws of food choices.

The situation is quite different when it comes to conscientious consumption that aims to shun the products of the intentional killing of animals. Here, owing in large part to long-standing cultural, social, and political norms of disclosing the ingredients of food, the provenance of products is clearer. A consumer can be relatively confident whether animals were killed intentionally to make a particular can of chili, ${ }^{38}$ whereas he or she cannot effectively tell whether, say, labor organizers were intimidated or blacklisted in making it. With the problem of judging provenance out of the way, the only epistemic issues on the table are the gravity of the flaw (how bad it is for us to kill an animal for food) and the effect of large-scale diet changes. Unlike the case of global supply chains, consumers are in just as good a position to make judgments about the gravity of the flaw (the killing of animals) as other actors are, and the effectiveness of aggregate consumer shifts away from meat eating appears uncontroversial.

Considering the epistemic status of one of the oldest and most well-known conscientious consumption policies, <shun meat $>$, provides something of an error theory as to why so many might ignore the threat of significant uncertainty and the cavalier dividend in other domains. The policy < shun meat $>$ is embedded in an informational infrastructure that allows consumers to be relatively effective enforcers of strict standards that prevent grave flaws to politically silent victims in protein supply chains. What we should not do is infer from the possible priority of conscientious consumption with regard to intentional animal killing to the priority of conscientious consumption in other domains, such as in response to grave flaws in global supply chains. That kind of conscientious consumption stands on much shakier ground. Instead, we have the better (or at least equally good) option of blundering blind and passing resources to more effective, epistemically wellpositioned actors both within and outside supply chains. The very moral considerations that are supposed to support conscientious consumption actually support consumption with relinquishment - that is, once we acknowledge the complexity of the world consumers must try to navigate.

\section{Acknowledgements}

I thank Wayne Norman, Allen Buchanan, Walter Sinnott-Armstrong, David Wong, Daniel Vermeer, Jennifer Hawkins, Gopal Sreenivasan, Katharine Brading, Kobi Finestone, Valerie Soon, Joe Nelson, Tim Burkhardt, Paul Henne, Sungwoo Um, Kian Mintz-Woo, Waheed Hussain, and David Schwartz for their insightful comments on earlier versions of this article. I am very grateful to three anonymous reviewers and the editor for their insightful and highly constructive feedback. I thank Princeton Open Access Publication Fund for enabling this publication to be open access.

\footnotetext{
${ }^{38}$ Of course, this case has some tricky epistemic issues. Informational infrastructure in the case of the treatment of animals kept for milk or eggs is much weaker. It seems very difficult to standardize and monitor "humane treatment" of animals. Veganism thus appears to be a more consistent policy than vegetarianism in this regard.
} 


\section{REFERENCES}

Adomaitis, Nerijus. 2018. "Statoil to Become Equinor, Dropping 'Oil' to Attract Young Talent." Business News, May 15. https://www.reuters.com/article/us-statoil-agmequinor/statoil-to-become-equinor-dropping-oil-to-attract-young-talent-idUSKC N1IG0MN.

Andreou, Chrisoula. 2006. "Environmental Damage and the Puzzle of the Self-Torturer." Philosophy and Public Affairs 34 (1): 95 -108.

Attari, Shahzeen Z., David H. Krantz, and Elke U. Weber. 2019. "Climate Change Communicators' Carbon Footprints Affect Their Audience's Policy Support." Climatic Change 154: 529-45.

Bacon, Christopher. 2005. "Confronting the Coffee Crisis: Can Fair Trade, Organic, and Specialty Coffees Reduce Small-Scale Farmer Vulnerability in Northern Nicaragua? "World Development 33 (3): 497 -511.

Barry, Christian, and Kate Macdonald. 2016. "How Should We Conceive of Individual Consumer Responsibility to Address Labour Injustices?" In Global Justice and International Labour Rights, edited by Yossi Dahan, Hanna Lerner, and Faina Milman-Sivan, 92-118. Cambridge: Cambridge University Press.

Barry, Christian, and Kate Macdonald. 2018. "Ethical Consumerism: A Defense of Market Vigilantism." Philosophy and Public Affairs 46 (3): 293 -322.

Barry, Christian, and Sanjay Reddy. 2008. International Trade and Labor Standards: A Proposal for Linkage. New York: Columbia University Press.

Bartley, Tim, Sebastian Koos, Hiram Samel, Gustavo Setrini, and Nik Summers. 2015. Looking Behind the Label: Global Industries and the Conscientious Consumer. Bloomington: Indiana University Press.

Booth, Philip, and Linda Whetstone. 2007. "Half a Cheer for Fair Trade." Economic Affairs 27 (2): $29-36$.

Bratman, Michael E. 1989. "Intention and Personal Policies." Philosophical Perspectives 3: 443-69.

Brock, Gillian. 2014. "Global Poverty, Decent Work, and Remedial Responsibilities.” In Poverty, Agency, and Human Rights, edited by Diana Tietjens Meyers, 119-45. Oxford: Oxford University Press.

Budolfson, Mark. 2015. "Consumer Ethics, Harm Footprints, and the Empirical Dimensions of Food Choices." In Philosophy Comes to Dinner, 173-91. New York: Routledge.

Budolfson, Mark. 2019. "The Inefficacy Objection to Consequentialism and the Problem with the Expected Consequences Response." Philosophical Studies 176: 1711-24.

Butt, Daniel. 2007. “On Benefiting from Injustice." Canadian Journal of Philosophy 37 (1): 129-52.

Cadot, Olivier, Daniel Traca, and Robert Crawford. 2001. "Soccer Balls Made for Children by Children?” INSEAD Case Study INS988. https://publishing.insead.edu/case/soc cer-balls-made-children-children-a-child-labor-pakistan.

Cafaggi, Fabrizio, and Andrea Renda. 2012. "Public and Private Regulation: Mapping the Labyrinth." Dovenschmidtz Quarterly 1 (1): 16 -33.

Cahalane, Claudia. 2015. "Fairphone Review: Ethics Trumps Everything Else." Guardian, January 15. https://www.theguardian.com/technology/2015/jan/15/fairphone-reviewethical-smartphone.

Calder, Todd. 2010. "Shared Responsibility, Global Structural Injustice, and Restitution." Social Theory and Practice 36 (2): 263-90. 
Chartier, Gary. 2006. "On the Threshold Argument against Consumer Meat Purchases." Journal of Social Philosophy 37 (2): 233-49.

De Janvry, Alain, Craig McIntosh, and Elisabeth Sadoulet. 2015. "Fair Trade and Free Entry: Can a Disequilibrium Market Serve as a Development Tool?" Review of Economics and Statistics 97 (3): 567-73.

Deloitte. 2018. "Deloitte Millennial Survey 2018.” https://www2.deloitte.com/tr/en/pages/ about-deloitte/articles/millennialsurvey-2018.html.

De Moor, Joost, and Soetkin Verhaegen. 2020. "Gateway or Getaway? Testing the Link between Lifestyle Politics and Other Modes of Political Participation." European Political Science Review 12: 91 -111.

Dragusanu, Raluca, Daniele Giovannucci, and Nathan Nunn. 2014. "The Economics of Fair Trade." Journal of Economic Perspectives 28 (3): 217 -36.

Eberhardt, Pia, and Cecilia Olivet. 2018. "Modern Pirates: How Arbitration Lawyers Help Corporations Seize National Assets and Limit State Autonomy." American Journal of Economics and Sociology 77 (2): 279 -329.

Engel, Jannis, and Nora Szech. 2020. “A Little Good Is Good Enough: Ethical Consumption, Cheap Excuses, and Moral Self-Licensing.” PLoS ONE 15 (1): 0227036.

Ethical Consumer. 2018. “Our Ethical Ratings.” June 1. https://www.ethicalconsumer.org/ about-us/our-ethical-ratings.

European Chemical Transport Association. 2011. "Guidelines for Measuring and Managing $\mathrm{CO}_{2}$ Emission from Freight Transport Operations." https://www.ecta.com/ resources/Documents/Best\%20Practices\%20Guidelines/guideline_for_measuring_ and_managing_co2.pdf.

Fairphone. n.d. "Responsible Sourcing from Conflict Areas." https://www.fairphone.com/ en/project/responsible-sourcing.

Ferguson, Benjamin, and Florian Ostmann. 2018. "Sweatshops and Consumer Choices." Economics and Philosophy 34 (3): 295 -315.

Føllesdal, Andreas. 2004. "Political Consumerism as Chance and Challenge." In Politics, Products and Markets: Exploring Political Consumerism Past and Present, edited by Michele Micheletti, Andreas Follesdal, and Stolle Dietlind, 3-20. New Brunswick, NJ: Transaction.

Frankel, Jeffrey A., and David H. Romer. 1999. "Does Trade Cause Growth?" American Economic Review 89 (3): 379-99.

Gamper-Rabindran, Shanti, and Stephen R. Finger. 2013. "Does Industry Self-Regulation Reduce Pollution? Responsible Care in the Chemical Industry." Journal of Regulatory Economics 43 (1): 1-30.

Givewell. 2016. "GiveWell Cost-Effectiveness Analysis-November 2016.” https://docs. google.com/spreadsheets/d/1KiWfiAGX_QZhRbC9xkzf3I8IqsXC5kkr-nwY_ feVlcM/edit\#gid=1034883018.

Good On You. n.d. "FAQs.” https://goodonyou.eco/faqs/.

Griffiths, Peter. 2012. "Ethical Objections to Fairtrade.” Journal of Business Ethics 105 (3): 357-73.

Harwatt, Helen, Joan Sabaté, Gidon Eshel, Sam Soret, and William Ripple. 2017. "Substituting Beans for Beef as a Contribution toward US Climate Change Targets." Climatic Change 143 (1-2): 261-70.

Hassoun, Nicole. 2015. "Consumption and Non-consumption." In The Routledge Handbook of Global Ethics, edited by Darrel Moellendorf and Heather Widdows, 279-90. London: Routledge. 
Hassoun, Nicole. 2019. "Consumption and Social Change.” Economics and Philosophy 35 (1): $29-47$.

Heath, Joseph, and Andrew Potter. 2004. The Rebel Sell: Why the Culture Can't Be Jammed. Toronto: HarperCollins.

Herzog, Lisa. 2019. "The Epistemic Division of Labor in Markets: Knowledge, Global Trade, and the Preconditions of Morally Responsible Agency." Economics and Philosophy. doi:10.1017/S0266267119000130.

Hochschild, Adam. 2006. Bury the Chains: Prophets and Rebels in the Fight to Free an Empire's Slaves. Boston: Houghton Mifflin Harcourt.

Hong, Lu, and Scott E. Page. 2004. "Groups of Diverse Problem Solvers Can Outperform Groups of High-Ability Problem Solvers." Proceedings of the National Academy of Sciences 101 (46): 16385-89.

Hong, Lu, and Scott E. Page. 2012. "Some Microfoundations of Collective Wisdom." In Collective Wisdom, edited by Jon Elster and Helene Landemore, 56-71. Cambridge: Cambridge University Press.

Hussain, Waheed. 2012a. "Is Ethical Consumerism an Impermissible Form of Vigilantism?" Philosophy and Public Affairs 40 (2): 111-43.

Hussain, Waheed. 2012b. "Stepping Up: Ethical Consumerism in a World of Diminished States." In Leadership and Global Justice, edited by Douglas A. Hicks and Thad Williamson, 157-74. New York: Palgrave Macmillan.

Hussain, Waheed. 2018. "Consumer Ethics: Complicity vs. Social Roles.” Unpublished manuscript.

Hyde, Alan. 2006. "A Game Theory Account and Defence of Transnational Labour Standards: A Preliminary Look at the Problem." In Globalization and the Future of Labour Law, edited by John D. Craig and S. Michael Lynck, 143-66. Cambridge: Cambridge University Press.

Hyde, Alan. 2009. "The International Labor Organization in the Stag Hunt for Global Labor Rights." Law and Ethics of Human Rights 3 (2): 154-79.

Jackson, Frank. 1991. "Decision-Theoretic Consequentialism and the Nearest and Dearest Objection." Ethics 101 (3): 461-82.

Kagan, S. 2011. "Do I Make a Difference?" Philosophy and Public Affairs 39 (2): 105-41.

Kingston, Ewan. 2020. "Consumer Ethics: Relinquishing Benefits from Under-regulated Markets." Unpublished manuscript.

Lawford-Smith, Holly. 2015. "Unethical Consumption and Obligations to Signal." Ethics and International Affairs 29 (3): 315-30.

Lawford-Smith, Holly. 2016. "Climate Matters Pro Tanto, Does It Matter All-ThingsConsidered?" Midwest Studies in Philosophy 40 (1): 129-42.

Legrain, Milli. 2019. "'Dignity and Respect': Dominican Factory Vows to Never Be a Sweatshop.” Guardian, February 14. https://www.theguardian.com/world/2019/ feb/14/alta-gracia-garment-factory-dominican-republic-living-wage.

Le Mare, Ann. 2008. "The Impact of Fair Trade on Social and Economic Development: A Review of the Literature." Geography Compass 2 (6): 1922-42.

Lichtenberg, Judith. 2010. "Negative Duties, Positive Duties, and the 'New Harms.'” Ethics 120 (3): 557-78.

Lichtenberg, Judith. 2014. Distant Strangers: Ethics, Psychology, and Global Poverty. Cambridge: Cambridge University Press.

Locke, Richard M. 2013. The Promise and Limits of Private Power: Promoting Labor Standards in a Global Economy. Cambridge: Cambridge University Press. 
Mazar, Nina, and Chen-Bo Zhong. 2010. "Do Green Products Make Us Better People?" Psychological Science 21 (4): 494-98.

Micheletti, Michele. 2003. Political Virtue and Shopping: Individuals, Consumerism, and Collective Action. London: Palgrave Macmillan.

Murray, Douglas, Laura Raynolds, and Peter Taylor. 2003. "One Cup at a Time: Poverty Alleviation and Fair Trade Coffee in Latin America." Fair Trade Research Group, Colorado State University. https://pdfs.semanticscholar.org/be14/674a2c084208b5fe 8e87dd9620138ecfb92c.pdf.

Nefsky, Julia. 2011. "Consequentialism and the Problem of Collective Harm: A Reply to Kagan." Philosophy and Public Affairs 39 (4): 364-95.

Nefsky, Julia. 2018. "Consumer Choice and Collective Impact." In Oxford Handbook of Food Ethics, edited by Anne Barnhill, Mark Budolfson, and Tyler Doggett, 268-86. Oxford: Oxford University Press.

Norcross, Alastair. 2004. "Puppies, Pigs, and People: Eating Meat and Marginal Cases." Philosophical Perspectives 18 (1): 229-45.

Olsen, Kristian. 2018. "Subjective Rightness and Minimizing Expected Objective Wrongness." Pacific Philosophical Quarterly 99 (3): 417-41.

O’Rourke, Dara. 2012. Shopping for Good. Cambridge, MA: MIT Press.

Page, Scott E. 2008. The Difference: How the Power of Diversity Creates Better Groups, Firms, Schools, and Societies. Princeton, NJ: Princeton University Press.

Parker, Dominic, Host Fernando Aragon, and Dominic P. Parker. 2017. "Resource Cursed or Policy Cursed?" Journal of the Association of Environmental and Resource Economists 4 (11): 1-49.

Pasternak, Avia. 2016. "Benefiting from Wrongdoing." In A Companion to Applied Philosophy, edited by Kasper Lippert-Rasmussen, Kimberley Brownlee, and David Coady, 411-23. New York: Wiley-Blackwell.

Pooler, Michael, and Rob Harrison. n.d. "Ethical Shopping and Price." http://www. ethicalconsumer.org/commentanalysis/consumerism/thepriceofethics.aspx.

Powell, Benjamin, and Matt Zwolinski. 2012. "The Ethical and Economic Case against Sweatshop Labor: A Critical Assessment.” Journal of Business Ethics 107 (4): 449-72.

Ronzoni, Miriam. 2016. "Global Labour Injustice: A Critical Overview." In Global Justice and International Labour Rights, edited by Yossi Dahan, Hanna Lerner, Faina Milman-Sivan, 26 -52. Cambridge: Cambridge University Press.

Rosen, Gideon. 2008. "Kleinbart the Oblivious and Other Tales of Ignorance and Responsibility." Journal of Philosophy 105 (10): 591 -610.

Ruben, Ruerd, ed. 2008. The Impact of Fair Trade. Wageningen, Netherlands: Wageningen Academic.

Ruggie, John. 2013. Just Business: Multinational Corporations and Human Rights. New York: W. W. Norton.

Ruggie, John. 2018. "Multinationals as Global Institution: Power, Authority and Relative Autonomy." Regulation and Governance 12 (3): 317-33.

Sandberg, Joakim. 2013. "Ethical Investment." In International Encyclopedia of Ethics, edited by Hugh LaFollette, 1-5. Malden, MA: Wiley-Blackwell.

Schrempf-Stirling, Judith, and Florian Wettstein. 2017. "Beyond Guilty Verdicts: Human Rights Litigation and Its Impact on Corporations' Human Rights Policies.” Journal of Business Ethics 145 (3): 545-62.

Schwartz, David T. 2010. Consuming Choices: Ethics in a Global Consumer Age. Lanham, MD: Rowman and Littlefield. 
Seidman, Gay W. 2007. Beyond the Boycott: Labor Rights, Human Rights, and Transnational Activism. New York: Russell Sage Foundation.

Sepielli, Andrew. 2018. "Subjective and Objective Reasons." In The Oxford Handbook of Reasons and Normativity, edited by Daniel Star, 785-98. Oxford: Oxford University Press.

Shepski, Lee. 2013. "Going the (Ethical) Distance.” Journal of Business Ethics 116 (2): 393-402.

Singer, Abraham A., and Hamish van der Ven. 2019. "Beyond Market, Firm, and State: Mapping the Ethics of Global Value Chains.” Business and Society Review 124 (3): 325-43.

Slater, Tamara L. 2015. "Investor-State Arbitration and Domestic Environmental Protection." Washington University Global Studies Law Review 14: 131-54.

Smith, Adam. (1776) 2003. The Wealth of Nations. New York: Bantam.

Smith, Holly. 1983. "Culpable Ignorance." Philosophical Review 92 (4): 543-71.

Szasz, Andrew. 2007. Shopping Our Way to Safety: How We Changed from Protecting the Environment to Protecting Ourselves. Minneapolis: University of Minnesota Press.

Vogel, David. 2007. The Market for Virtue: The Potential and Limits of Corporate Social Responsibility. Washington, DC: Brookings Institution Press.

Weitzman, Hal. 2006. "The Bitter Cost of 'Fair Trade' Coffee." Financial Times, September 8. https://www.ft.com/content/d191adbc-3f4d-11db-a37c-0000779e2340.

Wenar, Leif. 2016. Blood Oil. Oxford: Oxford University Press.

White, Gillian. 2015. “All Your Clothes Are Made with Exploited Labor.” Atlantic, June 3. https://www.theatlantic.com/business/archive/2015/06/patagonia-labor-clothingfactory-exploitation/394658.

Willis, Margaret M., and Juliet B. Schor. 2012. "Does Changing a Light Bulb Lead to Changing the World? Political Action and the Conscious Consumer." Annals of the American Academy of Political and Social Science 644 (1): 160 -90.

Worker Rights Consortium. n.d-a. "Mission.” https://www.workersrights.org/about.

Worker Rights Consortium. n.d-b. "What Are the WRC's Funding Sources?" https://www. workersrights.org/affiliates/frequently-asked-questions.

EWAN KIngSTON is a postdoctoral researcher at Princeton University in the University Center of Human Values and the Princeton Environmental Institute. He focuses on the practical political philosophy of global collective action problems and consumer ethics. He holds a PhD in philosophy from Duke University.

This is an Open Access article, distributed under the terms of the Creative Commons Attribution-NonCommercial-NoDerivatives licence (http://creativecommons.org/licenses/by-ncnd/4.0/), which permits noncommercial re-use, distribution, and reproduction in any medium, provided the original work is unaltered and is properly cited. The written permission of Cambridge University Press must be obtained for commercial re-use or in order to create a derivative work. 